\title{
Canine perianal furunculosis and interdigital lesions: Probable systemic lupus erythematosus
}

\author{
Descripción clínico-patológica de fístulas perianales y dermatitis interdigital \\ en un perro como posible diagnóstico de lupus eritematoso sistémico
}

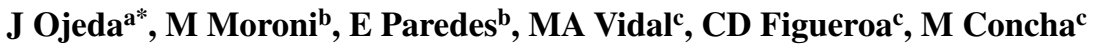 \\ anstituto de Ciencias Clínicas Veterinarias, Universidad Austral de Chile, Chile. \\ bInstituto de Patología Animal, Universidad Austral de Chile, Chile. \\ 'Instituto de Anatomía, Histología y Patología, Universidad Austral de Chile, Chile.
}

\begin{abstract}
RESUMEN
La clasificación de los signos clínicos del lupus eritematoso sistémico de acuerdo a su importancia en mayor o menor grado ha permitido orientar hacia un diagnóstico definitivo confirmado con la utilización de técnicas serológicas e inmunohistoquímicas. Un perro de raza Pastor alemán de cinco años de edad se presentó en el Hospital Veterinario de la Universidad Austral con una historia clínica de fístulas perianales y lesiones interdigitales en sus cuatro miembros, persistentes durante tres meses, que fue tratado con antibióticos. Los signos clínicos observados fueron alopecia, eritema, despigmentación, ulceración, excesiva presencia de tejido de granulación y dolor en la zona perianal e interdigital de los cuatro miembros. Además, presentó aumento de volumen en las articulaciones carpales y tarsales manifestando dolor en movimientos de flexión y extensión. Por medio de biopsias de zonas interdigitales y perianales tanto de áreas lesionadas como sanas, se realizó un análisis histopatológico. El examen mostró una separación parcial de la unión dermoepidérmica, presencia de detritus celulares, vacuolización de las células epidérmicas basales, abundante infiltrado histiocítico y linfoplasmocítico en la dermis con acumulo de eosinófilos en los vasos sanguíneos. Con tinción PAS se pudo observar una membrana basal discontinua y engrosada tanto en la piel sana como dañada. Además, los análisis inmunohistoquímicos mostraron reacción en la unión dermoepidérmica a IgM, $\operatorname{IgA~y~} \mathrm{C}_{3}$, pero no hubo reacción para IgG. Analizando los antecedentes clínicos, histopatológicos e inmunohistoquímicos se sugiere que el presente reporte es un caso de lupus eritematoso sistémico.
\end{abstract}

Key words: systemic lupus erythematosus, perianal furunculosis, autoimmune diseases.

Palabras clave: lupus eritematoso sistémico, furunculosis perianal, enfermedades autoinmunes.

\section{INTRODUCTION}

Systemic lupus erythematosus (SLE) is an autoimmune disease characterized by the production of a variety of autoantibodies (antinuclear antibodies, rheumatoid factor, antiphospholipid antibodies) which react against their own cellular antigens and also form immune complexes (IC) in circulating blood (Medlea and Hnilica 2006). The underlying cause of this loss of self- tolerance is unknown. In SLE IgM and IgG autoantibodies fix complement producing a direct cytotoxic effect or render cells susceptible to phagocytosis. Autoantibodies may also bind to platelets or red blood cells, explaining the immune-mediated anemia and thrombocytopenia found in SLE. IC are deposited in different tissues such as the vascular endothelium, glomeruli, synovial membranes and

Accepted: 16.06.2010.

* *Casilla 567, Valdivia, Chile; javierojeda@uach.cl articular capsule, as well as the basal membrane of the epidermis (Scott et al 2003). The fixation of complement by IC is a central step in the pathogenesis of the tissue injury observed in SLE. Complement activation induces anaphylatoxin generation and neutrophil infiltration. The latter produces phagocytosis of IC, and release of lysosomal enzymes and free radicals. IC also lead to aggregation of platelets and activation of Hageman factor which in turn contribute to the inflammatory process, local ischemia and necrosis (Abbas 2005, Thurman and Holers 2006). SLE is rare in cats and not very common in dogs, except for the German shepherd and Collie breeds which seem to be predisposed to this condition (Medlea and Hnilica 2006). The disease has shown a much higher prevalence in certain research kennels, higher than can be accounted for by genetics. In fact, the disease has been linked to certain class I major histocompatibility complex molecules in a line of German Shepherds (Teichner et al 1990). It has been suggested that environmental influences may also play a role as the disease is aggravated by exposure to 
sunlight in both dogs and humans. Several studies have also linked the onset of SLE to transmissible factors such as viruses, parasites or other infectious agents (Berent and Cerundolo 2005, Menke et al 2008).

\section{MATERIAL AND METHODS}

Clinical history: A 5-year old German shepherd dog, weighing $35 \mathrm{~kg}$, was presented to the Veterinary Hospital of the Universidad Austral de Chile with a history of perianal fistulas (figure 1a) and interdigital dermatitis (figure 1b) diagnosed 2 months previously based on clinical examination. The dog was initially treated with amoxi clavulanic acid at a dose of $20 \mathrm{mg} / \mathrm{kg} / 12$ hours and $2 \%$ topical chlorhexidine every 12 hours during 15 days without showing any clinical improvement.

Clinical examination: The initial clinical examination revealed painful perianal fistulas and serous discharge, the interdigital zones of the four limbs demonstrated alopecia, erythema, depigmentation, ulceration, serous discharge and granulation tissue. Moreover, it was evident that an increased volume of the carpal and tarsal articulations were causing a plantigrade footstep, and pain after forced flexion/extension evaluation (figure 1b). The hematology exam showed a normocytic macrocytic anemia $(27 \%$ PCV) with slight regeneration and eosinophilia $(2.8 \mathrm{mil} / \mu \mathrm{L})$, while biochemical values (ALT: 55U/L, Creatinine: $87 \mu \mathrm{mol} / \mathrm{L}, \mathrm{GGT}: 2 \mathrm{U} / \mathrm{L}$, Alkaline fosfatase: $159 \mathrm{U} / \mathrm{L}$, Uremia: $2.65 \mathrm{mmol} / \mathrm{L}$ ) and urine analysis were normal.

Histological studies: Skin biopsies of the perianal and interdigital areas were performed under general anesthesia. All biopsies were taken from affected skin and included a $1 \mathrm{~cm}$ margin of healthy looking skin. The biopsies were placed in $10 \%$ neutral buffered formalin, embedded in paraffin, sectioned at $4 \mu \mathrm{m}$ and stained with hematoxylin-eosin and Peryodic acid Schiff (PAS) for evaluation by light microscopy. The immunohistochemical characterization was performed using an antigen retrieval method (Peña-Münzenmayer et al 2005). In brief, tissue sections were incubated in buffer citrate- $\mathrm{HCl} \mathrm{pH} 6.0$ at $90^{\circ} \mathrm{C}$ in a microwave. Next, the sections were treated with $3 \%$ hydrogen peroxide for 15 minutes to inhibit endogen peroxidases. Then, the tissue sections were washed with phosphate-buffered saline and incubated consecutively with: polyclonal antibodies anti-IgG (P01214, DAKO, Carpintería, CA, USA), anti-IgM (P01215, DAKO), anti-IgA (P01216, DAKO) or anti-C 3 (Q0368, DAKO) biotinylated secondary antibody, and then with streptavidin-peroxidase complex (Kit LSAB Plus, DAKO). Peroxidases were revealed with diaminobenzidine. The preparations were counterstained with hematoxylin. The controls included omission of the first antibodies and their substitution by non-immune mouse or rabbit IgG.

\section{RESULTS AND DISCUSSION}

The histopathology exam revealed zones with epidermal erosions, moderate vacuolization of epidermal basal cells, partial separation of the epidermodermal junction and cellular debris (figure 1c). An abundant histiocytic and lymphoplasmacytic infiltrate was detected under the epidermis, extending between the hair follicles and reaching the deep zone of the dermis (figure 1d). Aggregates of eosinophils were evident in blood vessels. In the affected skin, the epidermis, epidermodermal junction and papillary dermis revealed immunoreactivity for $\operatorname{IgM}$ and $\mathrm{C}_{3}$ (figure $2 \mathrm{a}$ ). The dermis in healthy skin also showed deposits of $\operatorname{IgM}, \mathrm{C}_{3}$ and in a minor degree $\operatorname{IgA}$ (figure $2 \mathrm{~b}$ ). Both affected and healthy skin failed to reveal immunoreactivity to IgG. In addition, PAS method revealed a loss of basal membrane in injuried skin with areas of partial thickening in both affected and non-affected skin (figure 2d).

The clinical and morphologic features of this condition suggested an immunological base for the lesions and the following therapy was carried out: i) prednisone $2 \mathrm{mg} / \mathrm{kg}$ once a day during 15 days, which was gradually tapered every 7 days until reaching a dose of $0.25 \mathrm{mg} / \mathrm{kg}$ prescribed for the length of the dog's life; ii) ranitidine at $2 \mathrm{mg} / \mathrm{kg}$ once a day during 15 days; iii) cephalexine administered at $20 \mathrm{mg} / \mathrm{kg}$ every 12 hours during 10 days. Improvement of the perianal and interdigital lesions was apparent after 30 days of treatment without relapse. The immunosuppressor therapy was instituted as is usually prescribed for lupus and perianal furunculosis, and cases in which histopathology results support an immune-mediated process (Fournel et al 1992, Scott et al 2003, Doust et al 2005, Patterson and Camphell 2005).

Canine anal furunculosis is a chronic, painful, progressive inflammatory and ulcerative disease suspected to be immunomediated (Patterson and Campbell 2005). Moreover, the general histopathological examination, including interdigital lesions, corresponds to interface dermatitis. These histological features are characterized by an inflammatory infiltrate that abuts or obscures the dermoepidermal junction, similar to those observed in other immuned-mediated conditions such as discoid lupus erythematosus, systemic lupus erythematosus, fixed erythema, toxic epidermal necrolysis, dermatomyositis and erythema multiforme (Crowson and Magro 2001). In the present case the clinical signs, the results of histopathology and immunohistochemistry exams suggested a diagnosis compatible with SLE.

SLE is an autoimmune multisystem disease of protein manifestations with non-specific clinical signs. The guidelines of the American College of Rheumatology are valuable in establishing the diagnosis (Tan et al 1982). Based on this protocol, Berent and Cerundolo (2005) proposed SLE diagnosis based on the presence of certain signs classified as major and minor signs. The classification of signs from major (e.g. skin lesion, polyarthritis, 


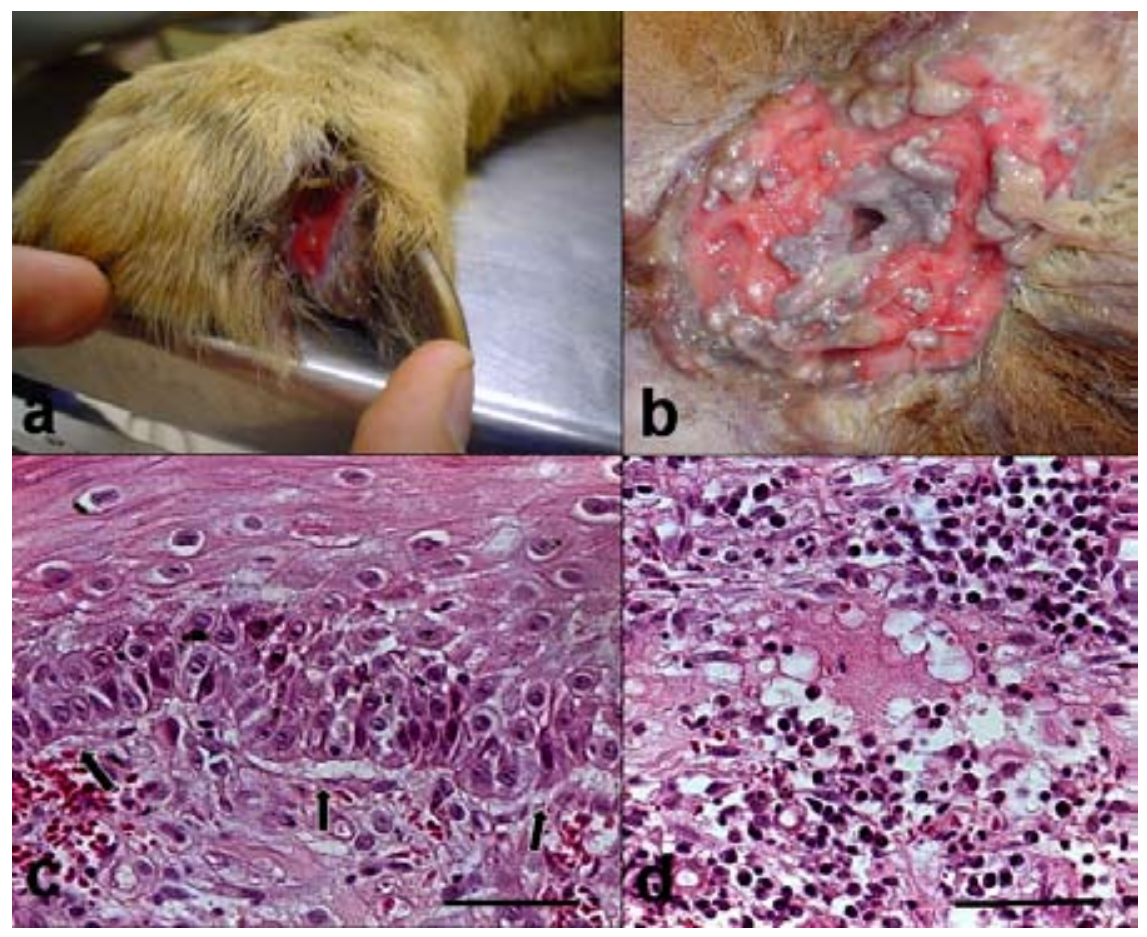

Figure 1. Interdigital (a) and perianal (b) lesions demonstrating alopecia, erythema and skin erosions. Hematoxylin eosin stain showed a dermoepidermal separation in lesional skin (c). Vacuolization of epidermal basal cells, abundant dermal histiocytic and lymphoplasmacytic infiltrate (d) Bar $60 \mu \mathrm{m}$.

Lesiones alopécicas y eritema sobre la piel de las zonas interdigital (a) y perianal (b). Tinción de hematoxilina eosina muestra a la separación de la unión dermoepidermal en piel afectada por lesiones (c). Vacuolización de las células basales de la epidermis, la dermis presenta abundante infiltrado histiocítico y linfoplasmocítico (d). Bar $60 \mu \mathrm{m}$.
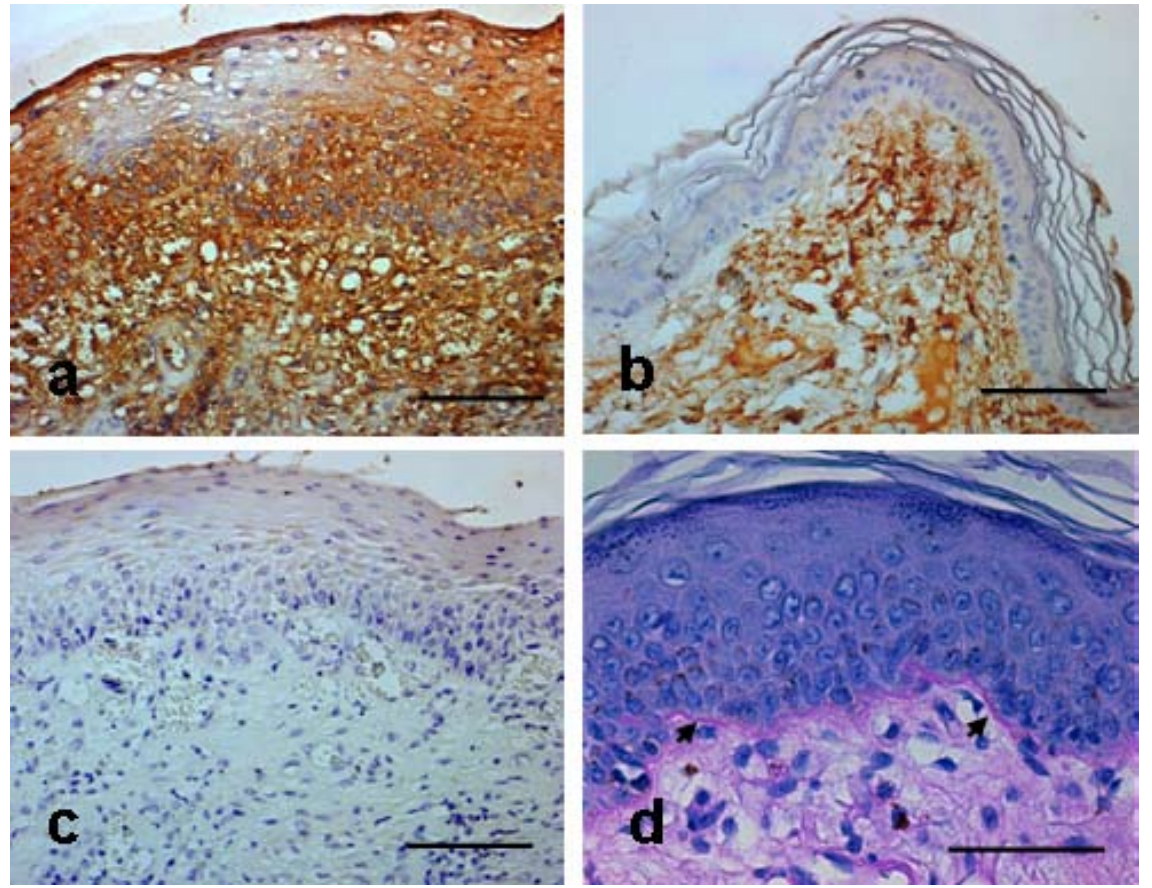

Figure 2. a) Immunoreactivity for $\mathrm{C}_{3}$ complement in dermoepidermal junction in skin with erosion. b) Dermic IgM deposits in uninvolved skin. c) Immunohistochemical control in damaged skin incubated with mouse non immune IgG. d) Moderate thickening of the basement membrane (arrows) in uninvolved skin, PAS reaction. (a-d, counterstained with hematoxylin; bar: a-c, $100 \mu \mathrm{m} ; \mathrm{d}, 60 \mu \mathrm{m}$ ).

a) Se observa inmunorreacción para fracción del complemento $C_{3}$ presente en unión dermoepidérmica de piel lesionada. b) Inmunorreacción de IgM en piel no lesionada. c) Control realizado con IgG de ratón en piel lesionada. d) Tinción PAS demuestra moderado engrosamiento de la membrana basal (flechas) en piel no lesionada. (a-d, contratinción realizada con hematoxilina; barra: a-c, $100 \mu \mathrm{m} ; \mathrm{d}, 60 \mu \mathrm{m}$ ). 
hemolytic anemia, glomerulonephritis, polymyositis, leucopenia, thrombocytopenia) to minor (e.g. fever of unknown origin, CNS signs, oral ulceration, lymphadenopathy) are good guides to establish a diagnosis. This classification is useful, and when applied in conjunction with serological and immunohistochemical tests, can lead to a more accurate diagnosis (Patterson and Campbell 2005, Smee et al 2007). Skin damage is classified among the major signs and they mean about $15 \%$ of the lesions under the suspicion of SLE (Smee et al 2007). Thus, signs observed in the present case such as anemia, polyarthritis and skin lesions at interdigital and perianal zones are classified as major signs of SLE.

In the present study we used immunoperoxidase techniques to demonstrate the presence of $\operatorname{IgM}$ and $\mathrm{C} 3$ at the epidermodermal junction in involved skin (Choi et al 2004) and $\operatorname{IgA}$ in uninvolved skin. The lupus band test showing $\operatorname{IgM}$ or $\operatorname{IgA}$ deposits at the basal membrane has been particularly important for the diagnosis of lupus erythematosus in humans. In addition, experimental models of systemic lupus erythematosus have demonstrated the presence of IgM and $\mathrm{C} 3$ at the dermoepidermal junction in damaged and non-damaged skin (Choi et al 2004). However, the immunoglulin deposition does not necessarily correlate with cutaneous lesions their prevalence in SLE is high. A wide array of autoantibodies are produced in SLE, therefore, searching particularly for antinuclear antibodies (ANA) is an important diagnostic tool. Since other major signs of SLE had been documented (i.e. polyarthritis, immunomediated anemia) in this reported case, the use of ANA would not have been as essential to support a diagnosis of SLE. In this case, the lack of a positive ANA and/ or the major signs of SLE (in addition to the skin lesions) make the final diagnosis of SLE impossible. Thus only a probable diagnosis of SLE can be made. Some authors emphasize that the test for ANA is effective only when there are at least 2 major signs (Smee et al 2007) because the presence of ANA may be associated with SLE-related diseases (Hansson-Hamlin et al 2006). The relevance of the ANA test for SLE in dogs has often been questioned due to the presence of these antibodies in several bacterial, protozoan and tick-borne pathogens (Gershwin 2007). Histopathological evidence, antibody deposits for IgM, $\operatorname{IgA}$ and $\mathrm{C} 3$ and PAS analysis of epidermodermal junction help to support the final clinical diagnosis as an SLE case (Zipfel et al 1992, Jones 1993, Gerhauser et al 2006).

Dogs with articular, muscle inflammation and cutaneous lupus manifestations improve after immunesupression treatment and may have a long term remission of clinical signs. Standard treatment for SLE with prednisone has been adequate to reach remission in the first week of treatment (Scott et al 2003). Nevertheless, many dogs do not improve with prednisone treatment and ciclosfosfamide or azathioprine may be needed. Azathioprine combined with prednisone is a safe and potentially effective regimen treatment of SLE (Berent and Cerundolo 2005, Medlea and Hnilica 2006).

Discoid lupus erythematosus could be associated to a clinical history of anal furunculosis or perianal dermatitis (Gerhauser et al 2006). However, hematological findings, interdigital wounds, carpal arthritis and tarsal arthritis discard this differential diagnosis.

Some authors have proposed a similarity between canine anal furunculosis and Crohn's disease. In humans, this illness is the result of an imbalance of the immune response in the intestines in genetically susceptible individuals (Ahmad 2002, Newman and Siminovitch 2005). Since German shepherd dogs with anal furunculosis also have clinical and histological evidence of colitis (i.e. inflammatory bowel disease), it has been suggested that enteral antigens could be a trigger forcanine anal furunculosis as well (Patterson and Campbell 2005). It has been speculated that immune complexes can damage perianal mucosa and subsequently induce furunculosis in SLE.

In conclusion, this was a case of chronic, erosive, and painful interdigital and perianal lesions with clinical characteristics of perianal fistula, developed in a German shepherd dog, and the histopathological and immunohistochemistry features were compatible with a diagnosis of SLE. Perianal lesions observed in this case represent an uncommon pattern of SLE. A complete study, including testing for circulanting antibodies in perianal dermatitis, can be useful in leading to an accurate diagnosis and treatment when there is suspicion of SLE, in orden to avoid the onset of other signs.

\section{SUMMARY}

The clinical signs of systemic lupus erythematosus (SLE) are not specific. The classification of signs according to their diagnostic importance from major to minor signs has proved to be useful, and when employed together with serological and immunohistochemical tests can lead to an accurrate diagnosis. Skin lesions are classified among the major signs corresponding to about $15 \%$ of lesions under the suspicion of SLE in dogs. A 5-year old German shepherd dog that was presented to clinical examination had developed perianal fistulas and infectious interdigital dermatitis. The dog was treated with antibiotics for 3 months and did not improve. Clinical signs included skin changes: alopecia, erythema, depigmentation, pain, ulceration and granulation tissue in the perianal zone and limbs, and articular changes: carpal and tarsal joint effusion and pain during the evaluation of forced flexion/extension. Histopathology from perianal and interdigital zones of affected skin revealed partial separation of epidermodermal junction and presence of cellular debris, moderate vacuolization of epidermal basal cells, and abundant dermal histiocytic and lymphoplasmacytic inflammatory infiltrate and collections of eosinophils in blood vessels. The Peryodic acid Schiff (PAS) reaction showed basal membrane discontinuity in diseased skin and partial thickening in both affected and healthy skin. Both affected and healthy skin revealed immunoreactions of $\operatorname{IgM}, \operatorname{IgA}$ and $\mathrm{C}_{3}$ but not of $\mathrm{IgG}$ at the epidermodermal junction. According to clinical, histopathology and immunohistochemistry evidence we suggest that the present report is a probable case of SLE. 


\section{REFERENCES}

Abbas A. 2005. Diseases of immunity. In: Kumar V, Abbas A, Fausto $\mathrm{N}$ (eds.) Pathologic Basis of Disease. $7^{\text {th }}$ ed. Elsevier, Philadelphia, USA, Pp 227-235.

Ahmad T, A Armuzzi, M Bunce, K Mulcahy-Hawes, S Marshall, T Orchard, J Crawshaw, O Large, A de Silva, J Cook, M Barnardo, S Cullen, K Welsh, D Jewell. 2002. The molecular classification of the clinical manifestations of Crohn's disease. Gastroenterology $122,854-866$.

Berent A, R Cerundolo. 2005. Systemic Lupus Erythematosus. Compend Contin Edu Pract Vet 11, 7-12.

Choi E, I Shin, H Youn, C Lee. 2004. Development of canine lupus erythematosus model. $J$ Vet Med Serie A 51, 375-383.

Crowson A, C Magro. 2001. The cutaneous pathology of lupus erythematosus: a review. J Cutan Pathol 28, 1-23.

Doust R, L Griffiths, M Sullivan. 2003. Evaluation of once daily treatment with cyclosporine for anal furunculosis in dogs. Vet Rec 152, 225-229.

Fournel C, L Chabanne, C Caux, J Faure, D Rigal, J Magnol, J Monier. 1992. Canine systemic lupus erythematosus. I: A study of 75 cases. Lupus 1, 133-139.

Gerhauser I, A Strothmann-Lüerssen, W Baumgärtner. 2006. A Case of Interface Perianal Dermatitis in a Dog: Is This an Unusual Manifestation of Lupus Erythematosus? Vet Pathol 43, 761-764.

Gershwin L. 2007. Autoimmune diseases in domestic animals. Ann N Y Acad Sci 1109, 109-116.

Hannson-Hamlin H, I Lilliehöök, G Trowald-Wigh. 2006. Subgroups of canine antinuclear antibodies in relation to laboratory and clinical finding in immune-mediated disease. Vet Clin Pathol 35, 397-404.

Jones D. 1993. Canine Systemic Lupus Erythematosus. New insights and their implications. J Comp Pathol 108, 215-228.
Medlea L, K Hnilica. 2006. Autoimmune and immune- mediated skin disorders. Small Animal Dermatology: a color atlas and therapeutic guide. Elsevier, Philadelphia, USA, Pp 206-211.

Menke J, MY Hsu, KT Byrne, JA Lucas, WA Rabacal, BP Croker, XH Zong, ER Stanley, VR Kelley. 2008. Sunlight triggers cutaneous lupus through a CSF-1-dependent mechanism in MRL-Fas(lpr) mice. J Immunol 181, 7367-7379.

Newman B, K Siminovitch. 2005. Recent advances in the genetics of inflammatory bowel disease. Curr Opin Gastroenterol 21, 401-407.

Patterson A, L Campbell. 2005. Managing Anal Furunculosis in Dogs. Compend Contin Edu Pract Vet 27, 339-355.

Peña-Münzenmayer G, M Catalán, I Cornejo, CD Figueroa, JE Melvin, MI Niemeyer, LP Cid, FV Sepúlveda: 2005. Basolateral localization of native $\mathrm{ClC}-2$ chloride channels in absorptive intestinal epithelial cells and basolateral sorting encoded by a CBS-2 domain di-leucine motif. J Cell Sci 118, 4243-4252.

Scott D, W Miller, C Griffin. 2003. Dermatología veterinaria. $6^{a}$ ed. Intermédica, Buenos Aires, Argentina, Pp 741-749.

Smee N, K Harkin, M Wilkerson. 2007. Measurement of serum antinuclear antibody titer in dogs with and without systemic lupus erythematosus: 120 cases (1997-2005). J Am Vet Med Assoc 230, 1180-1183.

Tan E, A Cohen, J Fries, A Masi, D Mcshane, N Rothfield, J Schaller, N Talal, R Winchester. 1982. The 1982 revised criteria for the classification of systemic lupus erythematosus. Arthritis Rheum 25, 1271-1277.

Teichner M, K Krumbacher, I Doxiadis, G Doxiadis, C Fournel, D Rigal, JC Monier, H Grosse-Wilde. 1990. Systemic lupus erythematosus in dogs: association to the major histocompatibility complex class I antigen DLA-A7. Clin Immunol Immunopathol 55, 255-262.

Thurman J, M Holers. 2006. The central role of the alternative complement pathway in human disease. J Immunol 176, 1305-1310.

Zipfel W, M Hewicker-Trautwein, G Trautwein. 1992. Demonstration of immunoglobulins and complement in canine and feline autoimmune and non-autoimmune skin diseases with the direct immunofluorescence and indirect immunoperoxidase method. J Vet Med Serie A 39, 494-501. 